\title{
Evaluation of operating conditions of cargo transportation by cabotage in Brazil: A multicriteria approach from the shipowners' point of view
}

\author{
A valiação das condições de operação do transporte de carga por cabotagem no Brasil: Uma \\ abordagem multicritério do ponto de vista dos armadores \\ Evaluación de las condiciones operativas del transporte de carga por cabotaje en Brasil: Un \\ enfoque multicriterio desde el punto de vista de los armadores
}

Received: 06/29/2021 | Reviewed: 07/05/2021 | Accept: 07/07/2021 | Published: 07/17/2021

\author{
Aldery Silveira Junior \\ ORCID: https://orcid.org/0000-0002-7852-9460 \\ University of Brasilia, Brazil \\ E-mail: aldery@unb.br \\ Rafael Rabelo Nunes \\ ORCID: https://orcid.org/0000-0002-1538-4276 \\ University of Brasilia, Brazil \\ E-mail: rafaelrabelo@unb.br \\ Evaldo César Cavalcante Rodrigues \\ ORCID: https://orcid.org/0000-0001-7176-2940 \\ University of Brasilia, Brazil \\ E-mail: evaldocesar@unb.br
}

\begin{abstract}
The purpose of this study was to develop and apply a model to evaluate the operating conditions of cargo transportation by cabotage in Brazil, from the perspective of Brazilian shipping companies operating in this segment. The evaluation model was developed based on the Multicriteria Decision Aid (MCDA) methodology, conceived under the constructivist paradigm and with the participation of a team of experts in cabotage, who built a framework for evaluation of this transportation mode. The global evaluation of the conditions of cargo transportation by cabotage in Brazil, based on this framework, was scored 3.9, - on a scale of zero to ten, - a score considered extremely low for a segment of cargo transportation so important and with such weight to the Brazilian economy. It was concluded that this score reflects the situation of shortage, neglect, and abandonment currently faced by shipping companies that offer cargo transportation services along the Brazilian coast. This work contributes to the construction of a multicriteria evaluation model, which can be replicated for other modes of transportation, with the necessary adjustments.
\end{abstract}

Keywords: Cabotage; Evaluation; Cargo; Brazil; MCDA.

\section{Resumo}

O objetivo deste estudo foi desenvolver e aplicar um modelo para avaliar as condições operacionais do transporte de carga por cabotagem no Brasil, a partir da perspectiva das empresas de navegação brasileiras que operam neste segmento. O modelo de avaliação foi desenvolvido com base na metodologia Multicriteria Decision Aid (MCDA), concebida sob o paradigma construtivista e com a participação de uma equipe de especialistas em cabotagem, que construiu uma estrutura para avaliação deste modo de transporte. A avaliação global das condições de transporte de carga por cabotagem no Brasil, com base nesta estrutura, foi pontuada em 3,9, - numa escala de zero a dez, - pontuação considerada muito baixa para um segmento do transporte de carga tão importante e com tal peso para a economia brasileira. Concluiu-se que esta pontuação reflete a situação de escassez, negligência e abandono enfrentada atualmente pelas empresas de navegação que oferecem serviços de transporte de carga ao longo da costa brasileira. Esse trabalho contribuiu na construção de um modelo de avaliação multicritério, que pode ser replicado para outros modos de transporte, com os ajustes necessários.

Palavras-chave: Cabotagem; Avaliação; Transporte; Brasil; MCDA.

\section{Resumen}

El objetivo de este estudio fue desarrollar y aplicar un modelo de evaluación de las condiciones operativas del transporte de carga por cabotaje en Brasil, desde la perspectiva de las empresas navieras brasileñas que operan en este segmento. El modelo de evaluación fue desarrollado con base en la metodología Multicriteria Decision Aid (MCDA), concebida bajo el paradigma constructivista y con la participación de un equipo de expertos en cabotaje, que construyeron un 
marco de evaluación de esta modalidad de transporte. La evaluación global de las condiciones del transporte de carga por cabotaje en Brasil, basada en este marco, tuvo una puntuación de 3,9, -en una escala de cero a diez-, puntuación considerada muy baja para un segmento de transporte de carga tan importante y con tanto peso para la economía brasileña. Se concluyó que esta puntuación refleja la situación de escasez, descuido y abandono a la que se enfrentan actualmente las empresas navieras que ofrecen servicios de transporte de carga en el litoral brasileño. La contribución deste trabajo consistió en la construcción de un modelo de evaluación multicriterio, que puede ser replicado para otros modos de transporte, con los ajustes necesarios.

Palabras clave: Cabotaje; Evaluación; Transporte; Brasil; MCDA.

\section{Introduction}

Brazil, due to its continental dimensions, has a maritime coast of about $7.400 \mathrm{~km}$ (Teixeira et al., 2015), in addition to approximately $1.600 \mathrm{~km}$ of waterway along the Amazon River to Manaus, in extension of the seacoast (BNDES, 1998), which gives it a natural vocation for cabotage - type of navigation carried out between ports or points in the national territory, using the sea route and the navigable waterways (Brasil, 1997).

Cabotage, in theoretical terms, can be used to reduce logistical costs. Despite the significant increase in the use of this mode of transport in recent years, it appears that its use is still below the full potential that exists in Brazil (Silveira Jr., 2018).

The little use of cargo transportation by cabotage is partly due to the predominance of road transportation, since the road mode, as Alvarenga (2020) is responsible for about $61 \%$ of cargo handling in Brazil. This fact overloads and congests the road system, unbalances the national transport matrix, and contributes to the increase in the country's logistical costs.

Other factors contribute to the low use of cabotage, such as: i) the total transport time, which is excessively long when compared to the road mode; and ii) freight cost which is currently not as advantageous as expected, due to economies of scale (Silveira Jr., 2018).

It is understood that the non-competitiveness of the freight price occurs due to the reduced volume of cargo transported by cabotage. If there was a considerable volume of cargo being transported by this modal, this price would certainly be more rewarding.

For a better development of cabotage in Brazil, legal and bureaucratic obstacles must be overcome, as well as policies and practices that allow the use of cabotage in conjunction with other modes should also be outlined (Silveira Jr., 2018).

Cabotage in Brazil reached the largest cargo handling among the modes in the 1920s and 1930s, mainly regarding the movement of general and bulk cargo, due to the limits and precarious conditions of highways and railways. Since then, the participation of this modality in the transport matrix has decreased, motivated initially by President Washington Luís' road construction policy, whose slogan was "to govern is to build roads" (Teixeira et al., 2018).

The decline in cabotage was accentuated in the 1950s and 1960s with the policy of substituting imports, which motivated the implantation of the automobile industry, the creation of the National Department of Roads and Highways (DNER) and the creation of Petrobrás, consolidating the road transport as the axis of development and interiorization of the country (Teixeira et al., 2018).

In the 1970s and 1980s, the oil crises, the rising inflationary process, the high costs and the low productivity of the ports contributed to make cabotage unfeasible for the transportation of general and containerized cargo, relying almost exclusively on the transport of solid and liquid bulk - large volumes of low added value (Silveira Jr., 2018).

In the early 1990s, a resumption of cabotage was attempted, motivated by the advent of Law on Modernization of Ports No. 8.630 / 93. This resumption, at first, ended up failing, due to the economic policy adopted at the time by the Brazilian government. However, at the end of the 1990s, with the stabilization of the economy, the control of inflation and the modernization of the ports, favorable economic and infrastructure conditions were created for the revitalization of cargo transport 
by cabotage (Silveira Jr., 2018).

Since then, the cargo transportation by cabotage has been growing continuously, but it still has a lot to grow to reach a volume of cargo transported enough to promote the reduction of the country's logistical cost.

The publication of the new model for the port sector - Law No. 12.815/13 (Brazil, 2013), aimed, ultimately, to promote greater use of cabotage, in view of the possibility of building "private ports", as well as the adoption of new port modalities. Such measures tend to contribute to the increase in port efficiency, with gains in agility, speed and efficiency in transshipment and cargo consolidation operations, which are fundamental factors for the development of cabotage, with a consequence in reducing the total logistical cost and increasing competitiveness of the national industry.

Few scientific studies have been carried out so far on Brazilian cabotage. In general, these studies were aimed at making qualitative diagnoses about the cabotage industry; and, as a rule, to indicate alternative solutions for the problems, difficulties and barriers detected.

This work changed its focus: it aimed to quantify the main factors that directly interfere in the operating conditions of this modal, and did so based on qualitative observations collected from operators of this type of transport.

With precise information about these factors, in terms of quantitative evaluation, conditions are created to define intervention priorities, as well as to monitor the evolution of each factor over time, based on successive measurements.

\section{Theoretical Reference}

According to Fonseca (2012), there are several versions for the emergence of the term cabotage, two of which stand out: i) the first derivative of coastal maritime transport carried out from stem to stern (between peninsulas); and ii) the second refers to the Italian navigator Sebastião Caboto, who, in the 16th century, explored the coast of North America, from Florida to the mouth of the São Lourenço River (exploration by the margins), and this practice became known as cabotage.

In Brazil, the term cabotage is directly related to waterway transport, including Law No. 9.432/97 defines cabotage navigation as "that carried out between ports or points in the Brazilian territory, using the sea route and the inland waterways" (Brazil, 1997). This does not occur in most other countries, where the term cabotage is almost always associated with domestic air transport.

In the specific case of the European Union, this name is associated with short sea shipping, which includes the concepts of domestic navigation (routes in the same country), international navigation (routes between European Community countries), including between continent and islands, and routes with non-European countries that have a coastline in the seas that border Europe (Valois, 2015).

Fonseca (2012) points out that, in the European Union, the term cabotage is also associated with road transport, but specifically with that carried out in the national territory of a country by foreign companies.

Regardless of the precision of its conceptualization, cabotage navigation, as Valois (2014) points out, presents, for cargo transportation, benefits and advantages, both in economic terms (lower freight cost), as well as social and environmental (less accidents in roads and lower emissions of pollutants), constituting a catalyst for the development of a sustainable transport system.

For these reasons, the study of the cabotage industry becomes attractive not only for verification of its benefits, but rather and mainly, for contributing to its development. Furthermore, the multimodal model, with the increase in cabotage, is the natural way to diversify the supply chain, as it enables the reduction of costs, the reduction of the risk of theft and accidents on the roads, in addition to minimizing the environmental impact (Borges et al., 2018). 
This item will address a general overview of cabotage in Brazil, the European Union and the United States, focusing on the characteristics of this mode of transportation, in addition to discussing the impacts of protectionist barriers and the economic and environmental benefits of this mode of transport.

\subsection{Cabotage in Brazil}

Cargo transportation is the support link for three important niches: the productive sector, commerce and consumers segments that dictate the pace and growth rates of the country.

The activity of cargo transportation, as an essential activity for the evolution of these segments, requires a reliable, balanced matrix, with viable costs and, preferably, with a low level of pollution and environmental degradation.

In the case of Brazil, it cannot be said that these characteristics are satisfactory, as there is an unbalanced matrix, highly dependent on the road modal, with about $61 \%$ of the volume of cargo transported by highways, as evidenced by Alvarenga (2020), despite the reality of Brazilian roads compromising the quality of road logistics (Silva et al., 2018). It contributes to more expensive carbo transportation, air pollution, and environmental degradation.

By legal force, the cabotage market in Brazil is restricted to Brazilian shipping companies with Brazilian flag vessels. However, Law No. 9.432/1997, made the institute more flexible, by stipulating that the chartering of a foreign vessel in coastal shipping could occur when the absence or unavailability of Brazilian flag vessels of the type and size suitable for the intended transportation (Brazil, 1997).

The cabotage market reserve for ships of Brazilian companies creates unfavorable situations for the efficiency of the country's transport matrix. This restriction contributes to the decrease in the number of available vessels and to the low levels of services in general verified. The breaking of the exclusivity of the national flag was pointed out by Durães Filho et al. (2011) as one of the initial structural reforms aimed at competitively recapacitating Brazilian cabotage.

In the early 1950 s, cabotage represented $27.5 \%$ of the volume of cargo transported in Brazil. From them on, with the increase in the road mode, encouraged by the Federal Government, there has been a sharp decline in the use of cabotage for the transportation of goods, to the point that in the 2000 s cabotage came to represent only $1.8 \%$ of the total cargo transported in the country, except for the transportation of oil and oil products (Carvalho, Robles \& Assumpção, 2010).

In the 1990s, there was the resumption of the Brazilian cabotage, driven in large part by the advent of Law 8.630, of 02/25/1993 - Modernization of Ports Law and favorable conditions in the Brazilian economy, such as inflationary control, economic stability, the opening and integration of the Brazilian economy to the foreign market (Camargos, 2002), which promoted the heating up of the industry, generating a greater demand for transport.

In this scenario, cabotage for cargo transportation (containerized or in bulk) is presented as a viable alternative for improving efficiency in the current transport system in the country, marked today by a disproportionate use of the road mode.

Some actions have been developed, both by the public authorities and by the private initiative, to boost trade through cabotage. However, some obstacles need to be overcome for this modal to continue to evolve in the country, such as (Silveira Jr., 2018): price of the bunker oil; poor port efficiency; slow bureaucratic processes that involve loading and unloading operations at the ports; and high waiting times for berthing solid and liquid bulk carriers.

In addition to the aforementioned obstacles, three others, of an economic nature - port taxes, labor service in ports (foreman and stevedoring) and pilotage service - contribute to the low use of cabotage, as their high costs pull up the cost of freight, making the modal less financially competitive in relation to road transport.

Ultimately, it should be noted that in recent years Brazilian cabotage has been showing significant growth. From 2010 to 2019 , the average growth rate for containerized cargo transport by cabotage was $13.57 \%$ per year. The other types of cargo 
(general cargo, solid bulk and liquid and gaseous bulk), presented the lowest annual average growth rates: $6.41 \%, 2.95 \%$ and $20.80 \%$, respectively (Brasil, 2020). Although these growth rates are attractive, especially in terms of containerized cargo, the use of cabotage in Brazil for cargo transport is still very low, especially when considering the favorable conditions that ex ist in the country: extension of the coast and concentration of the population near the coast.

\subsection{Economic and environmental benefits of cabotage}

Cabotage provides direct economic and environmental benefits to society, whether it is contributing to the reduction of the logistical cost in the country, reflected in the final price of the products, or in the reduction of the levels of pollutants discharged into the atmosphere by trucks and in the contribution to the preservation of highways.

There are several economic factors that indicate the advantage of cabotage in relation to other modes, such as lower freight prices and lower insurance expenses due to greater cargo security; such advantages contribute to the reduction of the country's logistical cost, with direct consequences for society (Silveira Jr., 2018).

Regarding to cargo handling capacity, a 5.000-ton vessel is capable of transporting the equivalent of 72 wagons or 143 trailers, so that, when opting for cabotage transport, it is possible to reduce the use of highways, as well as wear and tear, in addition to the possibility of reducing road accidents (CNT, 2013).

An important benefit of cabotage - and waterway transport in general - concerns the energy and environmental efficiency of this mode, since it presents a lower fuel consumption per ton-kilometer, when compared to other modes, which allows a lower cost per ton transported.

Figure 1 presents the fuel consumption for each mode of transport per ton transported per useful kilometer, it is observed that the consumption of road transport is almost twenty times greater than that of waterway (Barbosa, 2011).

Figure 1. Fuel consumption: liters / 1,000 TKU.

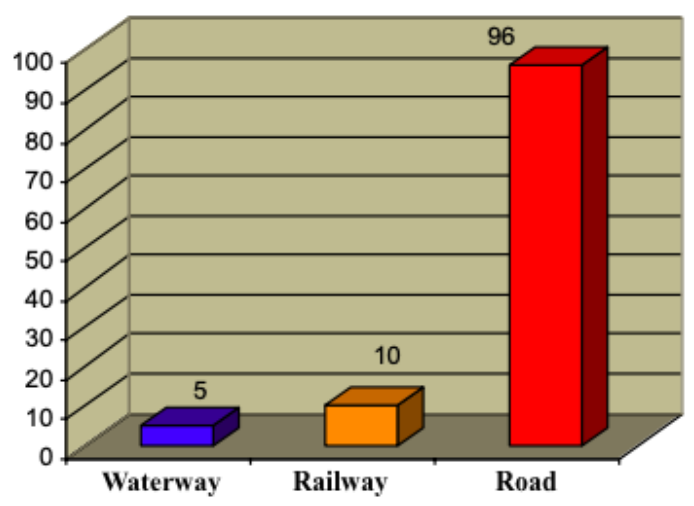

Source: Barbosa (2011).

In relation to energy use, as can be seen in Figure 2, water transport presents better energy efficiency when transporting 5 tons per $1 \mathrm{HP}$, almost 30 times more than road transport and almost seven times more than rail transport.

This better energy efficiency also has advantages in relation to fuel consumption and the consequent reduction in the emission of pollutants in relation to the transported cargo. Among these pollutants, there are carbon dioxide (CO2) and nitrogen oxide (NOx), which are responsible, among other effects on the environment, for the increase in temperature on the planet and for the formation of acid rains, respectively (Silveira Jr., 2018). 
It is evident that, regardless of the economic and environmental benefits resulting from the increased use of cabotage for cargo transportation, there are other equally important ones, such as the social benefits, arising from the decrease in the volume of trucks on the road, resulting in the reduction of congestion and the number of accidents caused by these vehicles.

Figure 2. Energy efficiency: load / power (t / HP).

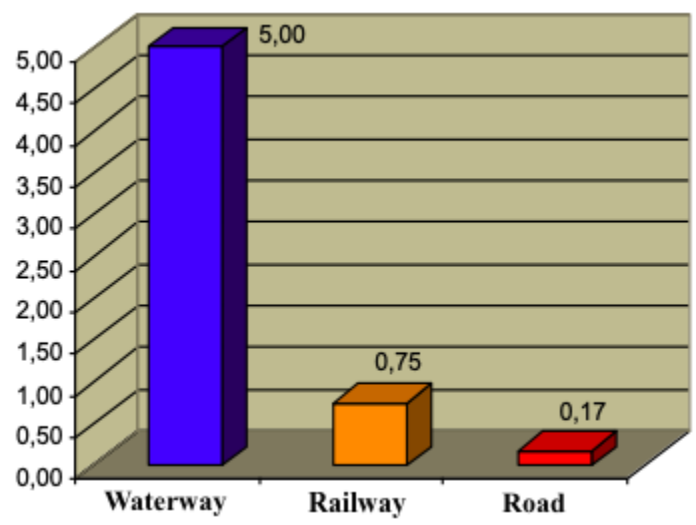

Source: Barbosa (2011).

\section{Methodological Approach}

The methodology used to carry out the study object of the present study was Multicriteria Decision Aid (MCDA). This methodology was chosen because it understands that it fits the purposes of the study, that is, a complex situation with a multiplicity of criteria to be evaluated. They refer to the new approach that emerged from the studies developed in France by Roy, in 1968 and in the United States by Keeney and Raiffa (1976) and Saaty (1977), authors considered the pioneers of the multicriteria decision aid methodology.

The MCDA methodologies, according to Ferreira et al. (2020), encompass different methods of decision analysis, among which the constructivist stands out, which served as the basis to support this study. Such methods have been used successfully both to support decisions that involve multiple objectives, and to assess real situations that face a multiplicity of objectives (criteria) and that are the result of decisions taken in the past (Silveira Jr., 2018).

This study fits exactly in the second case - evaluation of a real current situation (the conditions of operation of cargo transportation by cabotage) - which results from a series of decisions taken in the past, which directly impact the conditions faced by Brazilian shipping companies to provide cargo transportation services along the Brazilian coast and in the water basins that flow into the ocean.

In methodological terms, an evaluation model was initially developed based on the MCDA methodology, which will be briefly described below and, subsequently, a field research was carried out with the main Brazilian shipping companies operating in the segment of cargo transportation by cabotage, data were tabulated, partial and global assessments were calculated, and the respective analyzes were carried out.

The evaluation model was structured following the dictates and epistemological foundations proposed by Ensslin et al. (2001), and consisted of the basic steps:

- Definition of the problem label; 
- Identification of the actors involved in the evaluation process;

- Identification of the evaluation elements (criteria);

- Definition of descriptors;

- Construction of value functions;

- Determination of replacement rates (weights); and

- Construction of the value tree;

\subsection{Label}

Considering that the objective of the study was to evaluate the facilities and difficulties, in operational terms, incidents on the cargo transportation by cabotage, the label defined for the model was: evaluation of operating conditions of cargo transportation by cabotage in brazil.

\subsection{Actors}

Two types of actors participate directly in the process of structuring the evaluation models: decision-makers and facilitators. The decision-makers were composed of a group of high-level cabotage specialists, while the facilitators were the authors of the study, who provided the necessary tools and methodologies to elicit from the decision makers the information and knowledge required for the development of the various stages of the model.

\subsection{Criteria}

Six evaluation axes were defined, which correspond to the criteria or fundamental points of view (FPV). Due to their complexity, each criterion was broken down into subcriteria, called elementary points of view (EPV). The set of FPV and EPV constituted the value tree, which will be detailed at the end of the description of the construction of the evaluation model.

After completing the steps related to the construction of the "physical structure" of the multicriteria evaluation model, the next, more sensitive steps were developed, which concern the structuring of the internal aspects of the model, of a measuring nature of the actions that will be evaluated (potential actions). Such aspects are the descriptors, the value functions and the replacement rates.

\subsection{Descriptors}

The structure of the model allows a clear identification of the evaluation axes, which correspond to the complete details of each FPV. Thus, for each evaluation axis, which extends from FPV to a EPV (in the specific case there are eighteen axes), a criterion must be constructed to measure potential actions (Ensslin et al., 2001). An evaluation criterion consists of two tools: a descriptor and a value function.

There are several different methods in the literature that can be used to determine replacement rates. In this study, following the assumptions defined by Quirino (2002), we used the method of balanced weights (swing weights) to determine the replacement rates of FPVs (criteria) and the method of comparison pair by pair for EPVs (subcriteria).

\subsection{Value functions}

The value functions correspond, ultimately, to the scores that will be applied on the descriptors - set of levels of impact corresponding to the possible performances of the potential actions that will be evaluated (in the specific case, the subcriteria). 


\subsection{Replacement rates}

Replacement rates, also called compensation rates, express the loss of performance that a potential share must suffer in one criterion to offset the gain in another, in such a way that its global value remains unchanged, as evidenced by Bouyssou (1986), Keeney (1992), Keeney and Raifa (1993) and Roy (1996). Replacement rates are also known as "weights".

\subsection{Value tree}

After the replacement rates were determined, the structure of the evaluation model, with the criteria (FPV), subcriteria (EPV) and the respective replacement rates (weights) defined by the decision makers, the model tree, Figure 3, was defined.

Figure 3. Valuation model value tree

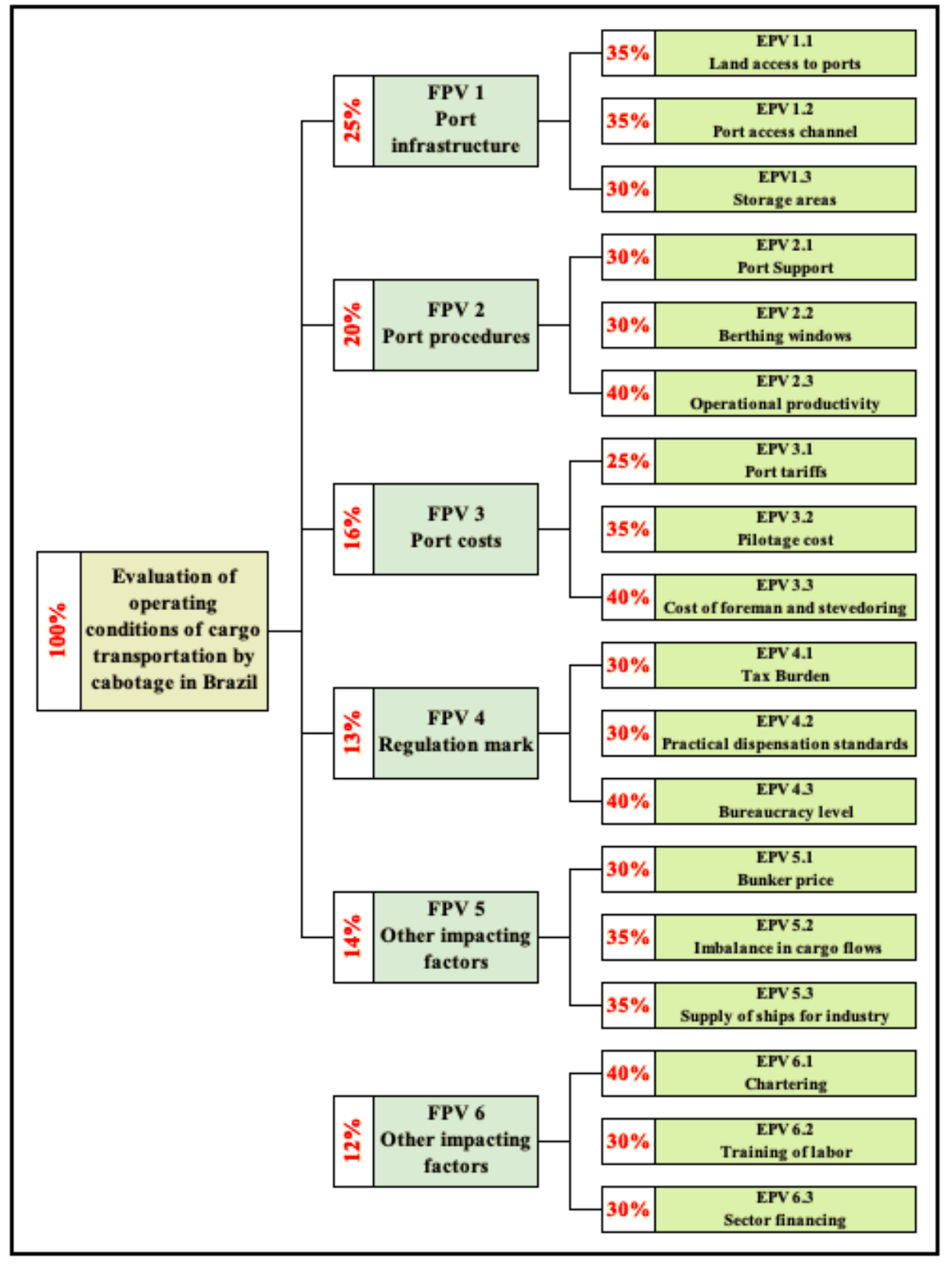

Source: Authors.

After the construction of the evaluation model was completed, the questionnaire that was applied in the field research 
was prepared. For the elaboration of this document, the subcriteria were started, which gave rise to the questions separately, and the descriptors constituted the alternatives for answering the questions.

\subsection{Procedures for calculating the assessment}

Considering that the final object of the present study is to carry out a quantitative assessment of the operating conditions of the activity of cargo transportation by cabotage, and that, for this purpose, six fundamental points of view were identified, which together are able to characterize such conditions of operation, it was understood that it would be pertinent to initially define a procedure to evaluate, as a whole, each FPV, since the research data, after treated by the Hiview3 software, would define only the score of each company, by FPV and globally.

With the quantitative assessment of each FPV, a second equation was defined for the calculation of the global assessment of the object of study, following, therefore, the fundamentals and guiding principles of the MCDA methodology, based on the premises defined by Ensslin et al. (2001).

For the calculation of the criteria evaluation (FPVs) - partial evaluations - the following additive aggregation formula was defined:

$$
\mathrm{E}(\mathrm{FPV})=\overline{\sum_{j=1}^{n}\left[\sum_{i=1}^{m} p i .(F V i E j)\right] .1 / n}
$$

Where:

- $\mathrm{E}(\mathrm{FPV})=$ evaluation of FPV;

- $\quad$ pi $=$ replacement rate (weight) of EPV i;

- $\quad(\mathrm{VFiEj})=$ value function of the Company $\mathrm{j}$ impacted on the EPV $\mathrm{i}$;

- $\mathrm{m}=$ number of subcriteria $(1,2$ and 3$)$;

- $\mathrm{n}=7$ (number of companies - 1, 2, 3, 4, 5, 6 and 7);

Such equation is subject to the following restrictions:

- $\quad$ the sum of the replacement rates must be equal to $1(\mathrm{p} 1+\mathrm{p} 2+\mathrm{p} 3=1 \rightarrow 100 \%)$;

- the replacement fee amount must be greater than zero and less than $1(0<$ pi < 1 , for $\mathrm{i}=1,2$ and 3);

- the Value Function of a potential action (E) with an impact on the Good level is equal to 100 in all criteria $($ VFi EGood $)=100$, for $\mathrm{i}=1,2$ and 3;

- the Value Function of a potential action (E) with an impact on the Neutral level is equal to zero in all criteria $-($ VFi ENeutral $)=0$, for $\mathrm{i}=1,2$ and 3 ;

For the calculation of the overall evaluation (final score), an additive aggregation formula was also defined, namely:

$$
\mathrm{OE}=\mid \sum_{i=1}^{n}\left[\sum_{i=1}^{k} x i \cdot y i(E j)\right] \cdot 1 / n
$$

Where:

- $\quad \mathbf{O E}=$ overall evaluation;

- $\quad \mathbf{y i}(\mathbf{E} j)=$ partial score of Company $\mathrm{j}$ in criteria $1,2,3,4,5$ and 6 ; 
- $\quad \boldsymbol{x} i=$ replacement rate for criteria $1,2,3,4,5$ and 6 ;

- $\quad \boldsymbol{n}=7$ (number of companies - 1, 2, 3, 4, 5, 6 and 7);

- $\quad k=6$ (number of criteria - 1, 2, 3, 4, 5 and 6)

This equation is subject to the following restrictions:

- $\quad$ the sum of the replacement rates for FPVs must be equal to $1(\mathrm{y} 1+\mathrm{y} 2+\mathrm{y} 3+\mathrm{y} 4+\mathrm{y} 5+\mathrm{y} 6=1 \rightarrow 100 \%)$;

- the value of the replacement fees must be greater than zero and less than 1 ( $0<$ yi < 1 , for $i=1,2,3,4,5$ e 6 );

- the Value Function of a potential action (E) with an impact on the Good level is equal to 100 in all criteria yi $($ EGood $)=100$;

- the Value Function of a potential action (E) with an impact on the Neutral level is equal to zero in all criteria - yi (ENeutral) =0;

- the total score of a potential EGood action with all impacts at the Good level is equal to $100-\mathrm{P}(\mathrm{EGood})=$ 100 ;

- the total score of a potential ENeutral action with all impacts at the Neutral level is equal to zero - P(ENeutral) $=0$

These two equations are sufficient to calculate the partial evaluations (FPV scores) and the overall evaluation (final score) from the data collected in the research, duly tabulated and treated which, in the last analysis, will constitute the indicative of the evaluations that we intend to reach.

\section{Research Data Presentation and Analysis}

The field research was carried out with the main shipping companies that operate with cargo transportation along the Brazilian coast and had the support of the National Waterway Transport Agency (Antaq), having been carried out in the midst of the partnership project signed between this Agency and the University of Brasilia, aimed at conducting a study on maritime navigation, encompassing the segments: long haul, cabotage, maritime support and port support (Brasil, 2015a).

There are forty companies registered with Antaq to operate in the cabotage segment; however, according to data from Antaq itself, in addition to companies operating in the oil and oil products transportation business, which is not part of this study, only seven companies operate effectively in cargo transportation, whether containerized cargo, loose cargo, solid bulk, liquid bulk (except oil and oil products), whether of gases. They are (Brasil, 2015b):

- Aliança Navegação e Logística Ltda.

- Norsul Navigation Company.

- Navigation company Elcano S / A.

- Flumar Transportes de Químicos e Gases Ltda.

- Log-In Logística Intermodal S / A.

- Mercosul Line Navegação e Logística Ltda.

- Tranship Transportes Marítimos Ltda.

Thus, these seven companies that constitute the study universe of the present work and, consequently, the object of the research conducted, which was conducted face-to-face with directors of six of these seven companies, with the application of a previously prepared questionnaire. One of the companies preferred to answer the questionnaire via the Internet, which, under no circumstances, impaired the survey.

The interviews for the application of the questionnaire were carried out at the headquarters of the companies, two in the 
city of São Paulo and four in the city of Rio de Janeiro. The interviews lasted from two to three hours, all of which were very productive, as they lasted from two to three hours, and were all very productive, once they discussed, in depth, the difficulties experienced by the companies to offer a service of quality, despite the barriers, bottlenecks, and adversity they face, and to keep up their double-digit annual growth rate in the last five years.

There is a consensus among the executives of the companies surveyed about the government's effort to improve the operating conditions of this mode, including praise for Antaq's performance. However, there is much to be done so that Brazilian cabotage can have a more significant participation in the Brazilian transportation matrix, to the point of being able to contribute effectively to the reduction of the country's logistical cost.

Next, the results of the research, the respective analyses, and the final considerations will be presented.

\subsection{Field research result}

The research was structured in six axes, characterized in the multicriteria model of evaluation developed for this study as Fundamental Points of View, namely:

- FPV 1 - Port infrastructure;

- FPV 2 - Port procedures;

- $\quad$ FPV 3 - Port costs;

- FPV 4 - Regulatory framework;

- $\quad$ FPV 5 - Other impacting factors;

- FPV 6 - Public policies;

Due to the complexity of these structuring axes to be measured, each of them was broken down into three Elementary Points of View, which constituted, individually, the "tips" of the evaluation axes, according to the multicriteria model developed (which was described in Chapter 4).

For presenting the research data and the respective analyzes, the companies will not be identified by name. They will be coded with the numbering from one to seven, without any correlation between the code and the respective company to which it refers.

The data regarding the answers of the several companies were treated by the Hiview3 software, based on the model developed for this study, considering the weights defined for the criteria and subcriteria, and the value functions assigned to the several impact levels, obtaining the global results presented in Figure 4. 
Figure 4. Weighted company scores.

\begin{tabular}{|c|c|c|c|c|c|c|c|c|c|c|}
\hline \multicolumn{5}{|l|}{ IS Cabetagem com MCDA Node Data } & & & & & \multirow{4}{*}{$\begin{array}{l}\text { Cumulative } \\
\text { Weigth }\end{array}$} & $0 \times 2=$ \\
\hline \multicolumn{5}{|c|}{ Cabotagem com MCDA - Weighted Scores } & \multirow{2}{*}{\multicolumn{2}{|c|}{ Company 5}} & \multirow{3}{*}{\multicolumn{2}{|c|}{$\begin{array}{l}\text { Company } 7 \\
\text { pany } 6\end{array}$}} & & \\
\hline \multirow{8}{*}{$\begin{array}{l}\text { Criteria } \\
\text { 1-Port infrastructure } \\
\text { 2- Port procedores } \\
\text { 3-Port costs } \\
\text { 4- Regulation mark } \\
\text { 5-Other factors } \\
\text { 6- Public policies }\end{array}$} & \multicolumn{2}{|c|}{ Company 1} & \multicolumn{2}{|c|}{ Company 3} & & & & & & \\
\hline & Weigth & $\mathrm{Ca}$ & pany 2 & \multicolumn{2}{|c|}{ Company 4} & Company 6 & & & & \\
\hline & 25 & 7,3 & 8,4 & 19,8 & 12,5 & 19,8 & 15,4 & 16,3 & 25,0 & \\
\hline & 20 & 7,3 & 8,4 & 19,8 & 12,5 & 19,8 & 15,4 & 16,3 & 20,0 & \\
\hline & 16 & 7,3 & 8,4 & 19,8 & 12,5 & 19,8 & 15,4 & 16,3 & 16,0 & \\
\hline & 13 & 7,3 & 8,4 & 19,8 & 12,5 & 19,8 & 15,4 & 16,3 & 13,0 & \\
\hline & 14 & 7,3 & 8,4 & 19,8 & 12,5 & 19,8 & 15,4 & 16,3 & 14,0 & \\
\hline & 12 & 7,3 & 8,4 & 19,8 & 12,5 & 19,8 & 15,4 & 16,3 & 12,0 & \\
\hline & 100 & 51 & 38 & 57 & 24 & 43 & 22 & 40 & 100 & \\
\hline
\end{tabular}

Source: Authors, using Hiview3 software.

The graph in Figure 5 shows the contribution of each FPV in the composition of the score of the companies that operate in the cabotage segment, and that were the subject of the research of this study.

The data presented here will be detailed, commented, and analyzed in the next section.

Figure 5. Contribution of each FPV to the score of companies.

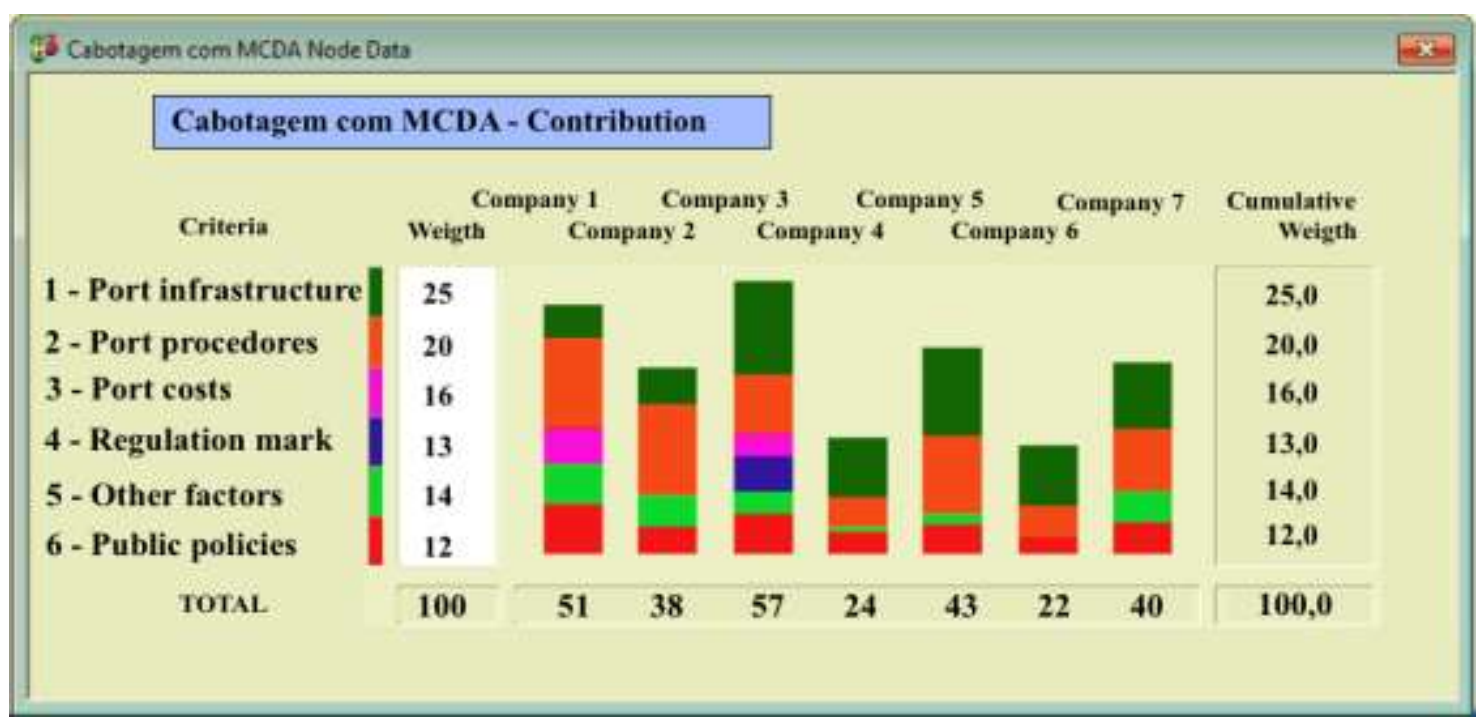

Source: Authors, using Hiview3 software.

\subsection{Data analysis}

The data, properly handled by the Hiview3 software, will be presented and analyzed by a Fundamental Point of View block. At the end, the global assessment will be presented, reflecting the operating conditions of cargo transportation by cabotage in Brazil, from the perspective of EBN, based on the decision-making parameters that participated in the construction of the multicriteria assessment model. 


\subsubsection{Port infrastructure}

The port infrastructure corresponds to the set of structural and non-structural elements that support port operations synthesized in berthing and unberthing of ships, embarkation and disembarkation and people and cargo. This set of elements can be broken down into the following groups: port facilities, protection structure and waterway access to the port, port equipment, land access routes to the port, port management and a regulatory framework that governs the organization, management and use of ports.

All these elements, in one way or another, are being considered in the various evaluative items that make up the developed model. However, in this specific FPV, called Port Infrastructure, only three elements are being evaluated: land access to ports, access channels and storage areas. The other elements will be analyzed, directly or indirectly, in the subsequent FPVs.

Table 1 shows a summary of the weighted scores assigned by Hiview3 to each of the companies for the three EPVs of this fundamental point of view, after due treatment of the data collected in the field research, as well as the final evaluation of this FPV, which fell short of what could be considered satisfactory, having reached the score 56.7.

Table 1. Composition of the FPV 1 evaluation.

\begin{tabular}{|c|c|c|c|c|c|c|c|c|c|}
\hline \multirow{2}{*}{ EPV } & \multirow{2}{*}{ Weights } & \multicolumn{7}{|c|}{ Value functions for each company } & \multirow{2}{*}{$\begin{array}{c}\text { FPV } \\
\text { Evaluation 1 }\end{array}$} \\
\hline & & $\# 1$ & $\# 2$ & $\# \mathbf{3}$ & $\# 4$ & \# 5 & \# 6 & $\# 7$ & \\
\hline 1.1 Land accesses & $35 \%$ & 40.0 & -40.0 & 40.0 & 0.0 & 40.0 & 40.0 & 0.0 & \multirow{4}{*}{56.7} \\
\hline 1.2 Access channels & $35 \%$ & 0.0 & 50.0 & 100.0 & 100.0 & 100.0 & 50.0 & 100.0 & \\
\hline 1.3 Storage areas & $30 \%$ & 50.0 & 100.0 & 100.0 & 50.0 & 100.0 & 100.0 & 100.0 & \\
\hline Weighted score by cc & & 29.0 & 33.5 & 79.0 & 50.0 & 79.0 & 61.5 & 65.0 & \\
\hline
\end{tabular}

Source: Authors, using Hiview3 software.

The low evaluation of this criterion is worrying, as it comprises three significant and impacting aspects for the transportation of cargo by cabotage. It should be noted, as appropriate, that this score 56.7 does not refer to a scale from 0 to 10 as the Lowest Weighted VF is -46.5 for this FPV, Table 2. Te difference for the two values gives 103.2, and, considering that the Weighted VF Range for this FPV is 208.75, we can obtain the score of $\mathbf{4 . 9}$ for FPV 1 in a scale from 0 to 10 , using a simple rule of three.

Table 2. Final evaluation of FPV 1.

\begin{tabular}{lccccccc}
\hline EPV & Weights & $\begin{array}{c}\text { Lowest Value } \\
\text { Function (VF) }\end{array}$ & $\begin{array}{c}\text { Highest Value } \\
\text { Function (VF) }\end{array}$ & $\begin{array}{c}\text { Amplitude } \\
\text { of VF }\end{array}$ & $\begin{array}{c}\text { Lowest } \\
\text { Weighted } \\
\text { VF }\end{array}$ & $\begin{array}{c}\text { Weighted } \\
\text { VF Range }\end{array}$ & $\begin{array}{c}\text { Weighted score } \\
\text { (from -50 to 175) }\end{array}$ \\
\hline 1.1 & $35 \%$ & -40 & 160 & 200 & -14.0 & 70.0 & 6.0 \\
\hline 1.2 & $35 \%$ & -50 & 175 & 225 & -17.5 & 78.75 & 25.0 \\
\hline 1.3 & $30 \%$ & -50 & 150 & 200 & -15.0 & 60.0 & 25.7 \\
\hline FPV Values 1 & & & & $\mathbf{- 4 6 . 5}$ & $\mathbf{2 0 8 . 7 5}$ & $\mathbf{5 6 . 7}$ \\
\hline
\end{tabular}

Source: Authors, using Hiview3 software.

Regarding to land access to ports, shipping companies considered it to be regular, bad, and terrible. This fact shows the precarious access to most Brazilian ports, which may contribute to discourage the use of the waterway for the flow of industrial 
or agricultural production to the different regions of the country.

The access channels were better evaluated by the companies consulted, having been considered by most of them as good, although two companies classified the access channels as regular and a single company as bad. The main complaint of the EBNs (Brazilian shipping company) in relation to this issue concerns the depth of some channels and the deficiency in the signaling of some of them.

In relation to the storage areas aspect, this was better evaluated than the last two. Considering the volume of cargo currently handled, most of the companies consulted believe that the storage areas made available by the ports meet the demand of the sector.

Finally, it should be noted that the lack of specific infrastructure for cabotage in Brazilian ports (exclusive port terminals) constitutes an inhibiting factor in the development of this mode of transport, since cabotage navigation competes, not on an equal footing, with long-distance navigation through port services and the installed physical infrastructure.

\subsubsection{Port procedures}

These procedures correspond to the activities destined to the necessary support to ships in ports, also including aspects related to berthing priorities offered by ports to cabotage ships, defined here as berthing windows.

The FPV related to port procedures, among the six FPVs evaluated, received the highest score: 69.7, as shown in Table 3.

Table 3. Composition of the FPV 2 evaluation.

\begin{tabular}{|c|c|c|c|c|c|c|c|c|c|}
\hline \multirow{2}{*}{ EPV } & \multirow{2}{*}{ Weights } & \multicolumn{7}{|c|}{ Value functions for each company } & \multirow{2}{*}{$\begin{array}{c}\text { FPV } \\
\text { Evaluation } 2\end{array}$} \\
\hline & & $\# 1$ & $\# 2$ & \# 3 & $\# 4$ & \# 5 & \# 6 & \# 7 & \\
\hline 2.1 Port support & $30 \%$ & 100.0 & 100.0 & 50.0 & 50,0 & 50.0 & -25.0 & 100.0 & \multirow{4}{*}{69.7} \\
\hline 2.2 Berthing windows & $30 \%$ & 167.0 & 100.0 & 100.0 & 0,0 & 100.0 & 100.0 & 100.0 & \\
\hline $\begin{array}{l}2.3 \text { Operational } \\
\text { productivity }\end{array}$ & $40 \%$ & 40.0 & 100.0 & 40.0 & 40,0 & 100.0 & 40.0 & 40.0 & \\
\hline Weighted score by company & & 96.1 & 100.0 & 61.0 & 31.0 & 85.0 & 38.5 & 76.0 & \\
\hline
\end{tabular}

Source: Authors, using Hiview3 software.

It should be noted, as appropriate, that this score 69.7 does not refer to a scale from 0 to 10 as the Lowest Weighted VF is -33.4 for this FPV, Table 4. Te difference for the two values gives 103.06, and, considering that the Weighted VF Range for this FPV is 192.5, we can obtain the score of $\mathbf{5 . 4}$ for FPV 2 in a scale from 0 to 10, using a simple rule of three.

Table 4. Final evaluation of FPV 2.

\begin{tabular}{lccccccc}
\hline EPV & Weights & $\begin{array}{c}\text { Lowest Value } \\
\text { Function (VF) }\end{array}$ & $\begin{array}{c}\text { Highest Value } \\
\text { Function (VF) }\end{array}$ & $\begin{array}{c}\text { Amplitude } \\
\text { of VF }\end{array}$ & $\begin{array}{c}\text { Lowest } \\
\text { Weighted VF }\end{array}$ & $\begin{array}{c}\text { Weighted } \\
\text { VF Range }\end{array}$ & $\begin{array}{c}\text { Weighted score } \\
\text { (from -40 to 167) }\end{array}$ \\
\hline 2.1 & $30 \%$ & -25 & 150 & 175 & $-7,5$ & 52,5 & 18,2 \\
\hline 2.2 & $30 \%$ & -33 & 167 & 200 & $-9,9$ & 60 & 28,6 \\
\hline 2.3 & $40 \%$ & -40 & 160 & 200 & -16 & 80 & 22,9 \\
\hline FPV Values 1 & & & & $-33,4$ & 192,5 & 69,7 \\
\hline
\end{tabular}


Although the EPVs of this FPV have obtained a slightly better evaluation than the EPVs of the previous criterion, it does not mean that these requirements are in a comfortable situation. Regarding to port support, the EBNs understand that the quality of the service provided falls short of what is charged.

In general, the services that make up the port support (support for the activities of berthing and unberthing the ships tugs, speedboats, moorings, etc.) are considered regular by the shipping companies, although there is a clear perception on their part that the the quality of such services is much better in private ports (TUP).

With regard to the dedicated windows for berthing ships in cabotage, a point that in the recent past represented a major problem for Brazilian cabotage, is currently close to an ideal situation, despite the absence of a guideline, in regulatory terms, for the preferential berthing of cabotage ships.

Some ports offer, on their own initiative, dedicated berthing windows for cabotage, just as, in some cases, port terminals, due to contracts signed with shipping companies, prioritize the berthing of ships that operate with cargo transportation on the Brazilian coast.

In terms of preferential berthing for cabotage ships, this problem could be overcome if there were specific guidelines in this direction, in terms of regulatory framework. Currently, only the port authorities are responsible for defining specific rules for berthing in their respective ports and not all of them give priority to cabotage.

The operational productivity of ports is seen as a major problem, especially in public ports, although there is a consensus on the part of the directors of the EBNs consulted that, in general, the productivity of ports in the south and southeast regions are better than that of ports of the Northeast and North regions. However, in both cases, there is an exception: there is a port in the southern region with productivity that leaves much to be desired, just as there is a port in the northeastern region with good productivity.

It should be noted, in due course, that Brazilian ports, in a general context, have much to improve, in terms of operational productivity, compared to the most efficient ports in the world, such as, for example, Rotterdam.

\subsubsection{Port costs}

The block to which this FPV refers includes three types of costs that considerably impact the cabotage cargo transportation system: port tariffs, pilotage and port labor (foreman and stevedoring). It was the FPV with the second worst evaluation, 4.6, on a scale of -40 to 167 (see Table 5 for a demonstration).

Table 5. Composition of the FPV 3 evaluation.

\begin{tabular}{|c|c|c|c|c|c|c|c|c|c|}
\hline \multirow{2}{*}{ EPV } & \multirow{2}{*}{ Weights } & \multicolumn{7}{|c|}{ Value functions for each company } & \multirow{2}{*}{$\begin{array}{c}\text { FPV } \\
\text { Evaluation } 3\end{array}$} \\
\hline & & $\# 1$ & $\# 2$ & \# 3 & \# 4 & \# 5 & \# 6 & $\# 7$ & \\
\hline 3.1 Port tariffs & $25 \%$ & 0.0 & -33.0 & 33.0 & 0.0 & 0.0 & 0.0 & 0.0 & \multirow{4}{*}{4.6} \\
\hline 3.2 Pilotage services & $25 \%$ & -40.0 & 0.0 & 0.0 & 0.0 & 0.0 & 0.0 & -40.0 & \\
\hline 3.3 Labor in ports & $40 \%$ & 150.0 & 0.0 & 50.0 & 0.0 & 0.0 & -25.0 & -25.0 & \\
\hline Weighted score by company & & 46.0 & -8.3 & 28.3 & 0.0 & 0.0 & -10.0 & -24.0 & \\
\hline
\end{tabular}

Source: Authors, using Hiview3 software.

It should be noted, as appropriate, that this score 4.6 does not refer to a scale from 0 to 10 as the Lowest Weighted VF is -32.25 for this FPV, Table 6. Te difference for the two values gives 36.82, and, considering that the Weighted VF Range for this FPV is 190, we can obtain the score of 1.9 for FPV 3 in a scale from 0 to 10, using a simple rule of three. 
It only reached this level because one of the companies surveyed impacted EPV 3.3 - Labor cost in the ports at level N5, the highest. And it did so under the allegation that it did not directly hire labor (foreman and stevedoring) at the ports, since such services were embedded in the contracts signed with the port terminals.

Table 6. Final evaluation of FPV 3.

\begin{tabular}{lccccccc}
\hline EPV & Weights & $\begin{array}{c}\text { Lowest Value } \\
\text { Function (VF) }\end{array}$ & $\begin{array}{c}\text { Highest Value } \\
\text { Function (VF) }\end{array}$ & $\begin{array}{c}\text { Amplitude } \\
\text { of VF }\end{array}$ & $\begin{array}{c}\text { Lowest } \\
\text { Weighted VF }\end{array}$ & $\begin{array}{c}\text { Weighted } \\
\text { VF Range }\end{array}$ & $\begin{array}{c}\text { Weighted score } \\
\text { (from -40 to 167) }\end{array}$ \\
\hline 3.1 & $25 \%$ & -33 & 167 & 200 & -8.25 & 50 & 0.0 \\
\hline 3.2 & $35 \%$ & -40 & 160 & 200 & -14 & 70 & -4.0 \\
\hline 3.3 & $40 \%$ & -25 & 150 & 175 & -10 & 70 & 8.6 \\
\hline FPV Values 1 & & & & -32.25 & 190 & 4.6 \\
\hline
\end{tabular}

Source: Authors, using Hiview3 software.

Port charges were rated by almost all companies as very high. Although there is variation in the value of the tariffs between ports, they are still very high in all ports. According to information from the surveyed companies, two of the ports in the southern region have the most expensive tariffs in the country.

The cost of piloting was considered by the directors of the EBNs surveyed to be very high and extremely high, although they are aware that the cost of this activity is relatively high worldwide. They even highlighted that there are countries in which this cost exceeds those practiced in Brazil.

According to information from the directors of the companies that participated in the survey, the value of piloting services in Brazilian ports costs an average of ten thousand US dollars per maneuver. And, when it comes to operations on the Amazon River, the cost of this service reaches one hundred thousand dollars for an operation up and down the river to the port of Manaus.

The Brazilian Association of Cabotage Shipowners (Abac) estimates that pilotage corresponds to 9 to $22 \%$ of the operational cost of cabotage (Abac, 2013), which is undoubtedly a very high percentage. This fact occurs, in part, due to the limited training of practitioners in Brazil and, therefore, the absence of competition in the midst of this activity.

The cost of foreman and stevedoring services is expensive in all ports, and in public ports, the cost is even higher. This occurs due to the obligation for ships to use the labor managed by the Labor Management Agency (Ogmo), not only due to the cost of the service itself, which is more expensive, but also because of the number of workers that is set by Ogmo for each type of operation. Usually, the number fixed is much higher than what is actually needed, from the BNB's point of view.

These three types of cost contribute to increase the cost of freight and, consequently, to inhibit potential users from making use of this type of transport to move their cargo.

\subsubsection{Regulation mark}

A regulatory framework is the set of legal diplomas that govern the cabotage activity. This FPV considered the legislation that deals with the tax burden on cargo transportation by cabotage, the rules of the Brazilian Navy that regulate the conditions and possibilities for exemption from piloting activity and the legislation responsible for the level of bureaucracy in the ports, both for ships and for cargo.

The regulatory framework was the worst-rated FPV. This does not mean that there is a general displeasure on the part of the EBNs with the cabotage regulatory framework; rather, it reflects their dissatisfaction with the legislation that deals with 
the issues addressed in this block.

The score of this FPV, after the treatment of the data by Hiview3, was negative and the lowest of all the fundamental points of view under analysis, -6.4 , on a scale that comprises, in its totality, scores from -50 to 200 , as shown in Table 7.

Table 7. Composition of the FPV 4 evaluation.

\begin{tabular}{|c|c|c|c|c|c|c|c|c|c|}
\hline \multirow{2}{*}{ EPV } & \multirow{2}{*}{ Weights } & \multicolumn{7}{|c|}{ Value functions for each company } & \multirow{2}{*}{$\begin{array}{c}\text { FPV } \\
\text { Evaluation } 4\end{array}$} \\
\hline & & \# 1 & $\# 2$ & \# 3 & $\# 4$ & \# 5 & \# 6 & \# 7 & \\
\hline 4.1 Tax burden & $30 \%$ & 0.0 & 0.0 & 0.0 & -33.0 & -33.0 & 0.0 & -33.0 & \multirow{4}{*}{-6.4} \\
\hline $\begin{array}{l}\text { 4.2 Practical dispensation } \\
\text { standards }\end{array}$ & $30 \%$ & -50.0 & -50.0 & 50 & -50.0 & -50.0 & -50.0 & -50.0 & \\
\hline 4.3 Level of bureaucracy & $40 \%$ & 0.0 & 0.0 & 0.0 & 0.0 & 0.0 & 0.0 & 0.0 & \\
\hline Weighted score by compa & & -15.0 & -15.0 & 55.0 & -4.9 & -24.9 & -15.0 & -24.9 & \\
\hline
\end{tabular}

Source: Authors, using Hiview3 software.

It should be noted, as appropriate, that this score -6.4 does not refer to a scale from 0 to 10 as the Lowest Weighted VF is -34.9 for this FPV, Table 8. Te difference for the two values gives 28.51, and, considering that the Weighted VF Range for this FPV is 199.9, we can obtain the score of $\mathbf{1 . 4}$ for FPV 4 in a scale from 0 to 10, using a simple rule of three.

Table 8. Final evaluation of FPV 4.

\begin{tabular}{lccccccc}
\hline EPV & Weights & $\begin{array}{c}\text { Lowest Value } \\
\text { Function (VF) }\end{array}$ & $\begin{array}{c}\text { Highest Value } \\
\text { Function (VF) }\end{array}$ & $\begin{array}{c}\text { Amplitude } \\
\text { of VF }\end{array}$ & $\begin{array}{c}\text { Lowest } \\
\text { wighted VF }\end{array}$ & $\begin{array}{c}\text { Weighted } \\
\text { VF Range }\end{array}$ & $\begin{array}{c}\text { Weighted score } \\
\text { (from -50 to 200) }\end{array}$ \\
\hline 4.1 & $30 \%$ & -33 & 150 & 183 & -9.9 & 54.9 & -4.2 \\
\hline 4.2 & $30 \%$ & -50 & 200 & 250 & -15 & 75 & -10.7 \\
\hline 4.3 & $40 \%$ & -25 & 150 & 175 & -10 & 70 & 8.6 \\
\hline FPV Values 1 & & & & 34.9 & 199.9 & -6.4 \\
\hline
\end{tabular}

Source: Authors, using Hiview3 software.

The tax burden was considered very high by all the EBNs surveyed. And it could not be different, given the incidence of various taxes and fees on cabotage, which contributes significantly to raising the price of freight.

It is observed that the rules of the Brazilian Navy are extremely strict when it comes to the commander of a ship dispensing the use of a Pilot in a certain port. In practice, the commander of a ship can only dispense with the use of the pilot in an area where the presence of this professional is mandatory on board, when the Commander himself is qualified as Pilot by the Directorate of Ports and Coasts of the Brazilian Navy (DPC), and for this qualification to happen, the rules are very strict.

The level of bureaucracy to which ships and cabotage cargoes are subject in ports is considered by most EBNs to be very excessive. It is understood that it could not be different, given that the study carried out by SEP / Idom (2015) identified that the number of documents that must be presented at ports, related to ships and cargo, exceeds forty (Brasil, 2015c). This number becomes more intriguing when compared to the documents required for the transportation of cargo by road, which are basically four: two from the truck (DUT and insurance) and two from the cargo (Invoice and Knowledge).

Among the documents that the cabotage vessels are required to carry, which is considered most incomprehensible by EBN, is the "Certificate of Free Practice", issued by the National Health Surveillance Agency - Anvisa, which must be revalidated 
in all ports where the ship berths. The understanding of shipping companies is that this document could well have a validity period of at least three months, when the ship is sailing only in Brazilian waters.

\subsubsection{Other impacting factors}

Besides the various factors that deal with the FPVs previously analyzed, three other factors were considered that directly impact the good performance of Brazilian cabotage, especially regarding the fact that they contribute to the increase in the price of freight. They are:

- $\quad$ price of fuel used by ships (bunker);

- $\quad$ unbalanced load flows on the south-north and north-south axes; and

- the availability of the Brazilian shipbuilding industry to meet the demand of the cabotage segment.

Other factors can also be considered impactful for the good performance of the cabotage segment, however, these three are the most significant.

This FPV scored slightly better than the two previous FPVs, reaching the 30.6 mark, on a scale ranging from -50 to 175 , Table 9.

Table 9. Composition of the FPV 5 evaluation.

\begin{tabular}{|c|c|c|c|c|c|c|c|c|c|}
\hline \multirow{2}{*}{ EPV } & \multirow{2}{*}{ Weights } & \multicolumn{7}{|c|}{ Value functions for each company } & \multirow{2}{*}{$\begin{array}{c}\text { FPV } \\
\text { Evaluation } 5\end{array}$} \\
\hline & & \# 1 & $\# 2$ & $\# 3$ & $\# 4$ & $\# 5$ & \# 6 & $\# 7$ & \\
\hline 5.1 Price of the bunker & $30 \%$ & 0.0 & 0.0 & 0.0 & 0.0 & 0.0 & 0.0 & 0.0 & \multirow{4}{*}{30.6} \\
\hline $\begin{array}{l}5.2 \text { Imbalance in cargo } \\
\text { flows }\end{array}$ & $35 \%$ & 175.0 & 50.0 & 50.0 & 50.0 & 50.0 & 0.0 & 50.0 & \\
\hline 5.3 Supply of ships & $35 \%$ & 0.0 & 100.0 & 43.0 & -28.0 & 0.0 & -28.0 & 100.0 & \\
\hline Weighted score by com & & 61.3 & 52.5 & 32.6 & 7.7 & 17.5 & -9.8 & 52.5 & \\
\hline
\end{tabular}

Source: Authors, using Hiview3 software.

It should be noted, as appropriate, that this score 30.6 does not refer to a scale from 0 to 10 as the Lowest Weighted VF is -42.3 for this FPV, Table 10. Te difference for the two values gives 72.9, and, considering that the Weighted VF Range for this FPV is 211, we can obtain the score of $\mathbf{3 . 5}$ for FPV 5 in a scale from 0 to 10, using a simple rule of three.

Table 10. Final evaluation of FPV 5.

\begin{tabular}{lccccccc}
\hline EPV & Weights & $\begin{array}{c}\text { Lowest Value } \\
\text { Function (VF) }\end{array}$ & $\begin{array}{c}\text { Highest Value } \\
\text { Function (VF) }\end{array}$ & $\begin{array}{c}\text { Amplitude } \\
\text { of VF }\end{array}$ & $\begin{array}{c}\text { Lowest } \\
\text { wighted VF }\end{array}$ & $\begin{array}{c}\text { Weighted } \\
\text { VF Range }\end{array}$ & $\begin{array}{c}\text { Weighted score } \\
\text { (from -50 to 200) }\end{array}$ \\
\hline 5.1 & $30 \%$ & -50 & 175 & 225 & -15 & 67.5 & 0.0 \\
\hline 5.2 & $35 \%$ & -50 & 175 & 225 & -17.5 & 78.75 & 21.3 \\
\hline 5.3 & $35 \%$ & -28 & 157 & 185 & -9.8 & 64.75 & 9.4 \\
\hline FPV Values 1 & & & & -42.3 & 211 & 30.6 \\
\hline
\end{tabular}

Source: Authors, using Hiview3 software.

When analyzing the EPVs in isolation, it is observed that the score attributed to all companies for the item "bunker price" was zero, as shown in Table 4.9. This low score reflects the dissatisfaction, on the part of EBN, with the practice adopted 
by the Brazilian government in surcharging bunker used by cabotage navigation at a different level from the bunker available for long course navigation, mainly due to the fact that there is legislation that establishes the isonomy of conditions for the fuel of these two segments of waterway navigation.

Law No. 6.432 establishes, in its Article 12, the following: "the fuel prices charged to long-haul vessels are extended to vessels operating in cabotage navigation and in port and maritime support navigations.". However, this legal precept is not fulfilled, since the ICMS is charged on the cabotage bunker, with rates ranging from 12 to $17 \%$, while for long course navigation this rate is zero.

Considering that fuel costs are between 35 and 50\% of the operational cost of cabotage (Abac 2013), it is seen that this taxation has a significant impact on the measurement of freight prices for cargo transport by cabotage.

On the other hand, truck fuel, the main competitor of cabotage, even for long distance routes, receives government subsidy, which, in a way, contributes to the lack of incentive to use cabotage for cargo transportation.

The imbalance in cargo flows in the south-north and north-south directions considerably affects the good performance of cargo transportation by cabotage, increasing the cost of freight. This is the opinion of most of the consulted EBNs. In the south-north direction, there is always more volume of cargo to be transported than in the north-south direction. However, some EBNs understand that this fact is normal and is part of the business, even claiming that this imbalance happens anywhere in the world: there is always a sense of flow with a greater volume of cargo than another.

The supply of ships by the national cabotage industry is characterized by most shipping companies as a major problem in the sector, as the installed capacity of the shipbuilding area is unable to meet the demand of the cabotage sector. This is aggravated mainly by the fact that the financing line with resources from the Merchant Marine Fund (FMM) for the construction and repair of vessels is only available for use in national shipyards.

Even so, some companies give up using FMM resources and order ships at international shipyards, bearing, in this case, a very high tax burden, not having the right to use their shares of AFRMM resources to finance such acquisitions. Such fact also happens with the repairs and modernizations of vessels. Some companies even send their ships to Chinese shipyards, paying much higher expenses and with their own resources, because, in these cases, they are not entitled to financing, simply because, depending on the national industry, the loss would certainly be greater.

\subsubsection{Public policies}

There are several public policies that directly or indirectly affect the transportation of cargo by cabotage, however this FPV deals only with three government policies: chartering of vessels, training of specialized labor and financing aimed at the cabotage segment.

This FPV obtained the second highest score among the other fundamental points of view analyzed, reaching 57.9 points, on a scale ranging from -50 to 150 , Table 11 . 
Table 11. Composition of the FPV 6 evaluation.

\begin{tabular}{|c|c|c|c|c|c|c|c|c|c|}
\hline \multirow{2}{*}{ EPV } & \multirow{2}{*}{ Weights } & \multicolumn{7}{|c|}{ Value functions for each company } & \multirow{2}{*}{$\begin{array}{c}\text { FPV } \\
\text { Evaluation } 6\end{array}$} \\
\hline & & \# 1 & $\# 2$ & \# 3 & $\# 4$ & \# 5 & \#6 & \# 7 & \\
\hline 6.1 Chartering vessels & $40 \%$ & 150.0 & 50.0 & 100.0 & 100.0 & 100.0 & 50.0 & 50.0 & \multirow{4}{*}{57.9} \\
\hline 6.2 Workforce training & $30 \%$ & 0.0 & 50.0 & 50.0 & 0.0 & 50.0 & 50.0 & 50.0 & \\
\hline $\begin{array}{l}6.3 \text { Financing for the } \\
\text { sector }\end{array}$ & $30 \%$ & 100.0 & 50.0 & 50.0 & 0.0 & 0.0 & 0.0 & 100.0 & \\
\hline \multicolumn{2}{|c|}{ Weighted score by company } & 90.0 & 50.0 & 70.0 & 40.0 & 55.0 & 35.0 & 65.0 & \\
\hline
\end{tabular}

Source: Authors, using Hiview3 software.

It should be noted, as appropriate, that this score 57.9 does not refer to a scale from 0 to 10 as the Lowest Weighted VF is -37.4 for this FPV, Table 12. Te difference for the two values gives 95.26, and, considering that the Weighted VF Range for this FPV is 187.4, we can obtain the score of $\mathbf{5 . 1}$ for FPV 6 in a scale from 0 to 10, using a simple rule of three.

Table 12. Final evaluation of FPV 6.

\begin{tabular}{lccccccc}
\hline EPV & Weights & $\begin{array}{c}\text { Lowest Value } \\
\text { Function (VF) }\end{array}$ & $\begin{array}{c}\text { Highest Value } \\
\text { Function (VF) }\end{array}$ & $\begin{array}{c}\text { Amplitude } \\
\text { of VF }\end{array}$ & $\begin{array}{c}\text { Lowest } \\
\text { wighted VF }\end{array}$ & $\begin{array}{c}\text { Weighted } \\
\text { VF Range }\end{array}$ & $\begin{array}{c}\text { Weighted score } \\
\text { (from -50 to 200) }\end{array}$ \\
\hline 6.1 & $40 \%$ & -50 & 150 & 200 & -20 & 80 & 34.3 \\
\hline 6.2 & $30 \%$ & -25 & 150 & 175 & -7.5 & 52.5 & 10.7 \\
\hline 6.3 & $30 \%$ & -33 & 150 & 183 & -9.9 & 54.9 & 12.9 \\
\hline FPV Values 1 & & & & -37.4 & 187.4 & 57.9 \\
\hline
\end{tabular}

Source: Authors, using Hiview3 software.

The chartering of vessels, which is a practice of great value for Brazilian cabotage, as it allows the supply of vessels, in specific situations, to meet the demand for cargo transportation, is one of the topics addressed by Law 9.432 / 97 - which deals with the ordering of waterway transport. Its regulation was recently reviewed by Antaq through Normative Resolution No. 1/2015 (Brasil, 1997; Brasil, 2015d).

According to the directors of the EBNs surveyed, the current vessel chartering policy, in force since 2015, meets the needs of the industry, which is why this item was well evaluated.

The training of specialized manpower (officers) to crew cabotage ships has been, in the view of the EBN, a recurring problem, because they understand that the two schools for training officers for the Merchant Navy, maintained and operated by the Brazilian Navy, one located in the city of Rio de Janeiro and the other in the city of Belém, cannot satisfactorily meet the needs of the sector. The direct consequence of the scarcity of this type of professional in the market is the increase in its cost.

However, at the present moment, due to the slowdown in Petrobras' activities and, consequently, the reduction in offshore support operations, there is an abundant supply of professionals in this category in the market. Even so, most shipping companies understand that the policy for training specialized labor partially meets the sector's demand, they believe that the current situation is temporary and that as soon as the economic activity is re-established there will be a lack of specialized labor in the market.

The financing policy for the cabotage sector is understood, by the EBNs, as deficient, in what concerns the financing instruments for construction and reform of ships, regarding the lack of lines of financing aimed at the operations of cargo 
transportation by cabotage.

There are two instruments aimed at supporting, in terms of financing, the construction and repair of ships for Brazilian shipping companies: Merchant Marine Fund (FMM) and the Guarantee Fund for Naval Construction (FGCN), namely:

- $\quad$ FMM - Fund administered by the Ministry of Transport to provide resources for the development of the Merchant Navy and the Brazilian shipbuilding and repair industry, whose resources come from the AFRMM and the Union Budget, with the National Development Bank as the financial agent Economic and Social (BNDES) and official banks; and

- $\quad$ FGCN - Private fund, managed by Caixa Econômica Federal, with the purpose of guaranteeing the credit risk of financing operations for the construction or production of vessels, as well as also guaranteeing the performance risk of Brazilian shipyards. It does not have any type of guarantee or endorsement from the public sector.

According to shipping companies, there is a major bureaucratic obstacle to the use of AFRMM resources, when they are released. The process for final approval of a ship construction or renovation project takes about two years.

Another major obstacle to the use of AFRMM resources relates to the Federal Government's release of such resources. Currently, the shares of AFRMM resources to which shipping companies that operate with cabotage are entitled and that are awaiting release reach considerable values. One of the companies surveyed stated that it has been waiting for some time for the release of funds in the order of more than $\mathrm{R} \$ 200$ million reais.

Brazilian shipping companies that operate in the cabotage segment are anxious for the Government to review the current practice of releasing resources so that they can effectively use the resources to which they are entitled.

Finally, it should be noted that, according to the report of the study carried out by SEP / Idom, focused on the development of cabotage, no specific financing lines were identified to support the operation of shipping companies operating in the cabotage segment. This fact reflects the lack of any kind of incentive in this direction, in terms of government policy.

Once the data for the various criteria, subcriteria, and the respective ones, have been presented, the next section will address the overall evaluation of the operating conditions of the navigation segment under analysis.

\subsection{Overall evaluation}

The global assessment of the cabotage cargo transport operating conditions in Brazil, from the perspective of the EBNs, reached 39.2 points, on a scale of - 50 to 200, as shown in Table 13, which presents the scores of the different FPVs by company and the overall evaluation. 
Table 13. Overall evaluation.

\begin{tabular}{|c|c|c|c|c|c|c|c|c|c|}
\hline \multirow{2}{*}{ FPV } & \multirow{2}{*}{ Weights } & \multicolumn{7}{|c|}{ Value functions for each company } & \multirow{2}{*}{$\begin{array}{c}\text { FPV } \\
\text { Evaluation }\end{array}$} \\
\hline & & \# 1 & $\# 2$ & $\# 3$ & $\# 4$ & \# 5 & \# 6 & $\# 7$ & \\
\hline 1. Port infrastructure & $25 \%$ & 29.0 & 33.5 & 79.0 & 50.0 & 79.0 & 61.5 & 65.0 & \multirow{7}{*}{39.2} \\
\hline 2. Port procedures & $20 \%$ & 96.1 & 100.0 & 61.0 & 31.0 & 85.0 & 38.5 & 76.0 & \\
\hline 3. Port costs & $16 \%$ & 46.0 & -8.3 & 28.3 & 0.0 & 0.0 & -10.0 & -24.0 & \\
\hline 4. Regulatory framework & $13 \%$ & -15.0 & -15.0 & 55.0 & -4.9 & -24.9 & -15.0 & -24.9 & \\
\hline $\begin{array}{l}\text { 5. Other impacting } \\
\text { factors }\end{array}$ & $14 \%$ & 61.3 & 52.5 & 32.6 & 7.7 & 17.5 & -9.8 & 52.5 & \\
\hline 6. Public policies & $12 \%$ & 90.0 & 50.0 & 70.0 & 40.0 & 55.0 & 35.0 & 65.0 & \\
\hline \multicolumn{2}{|l|}{ Weighted score by company } & 51.3 & 38.5 & 56.6 & 23.9 & 42.6 & 22.4 & 39.5 & \\
\hline
\end{tabular}

Source: Authors, using Hiview3 software.

Transforming the score for the overall evaluation to a scale of 0 to 10 , the final score is 3.9 . Undoubtedly, it is a very low grade for a segment of the cargo transport activity that is so important and with such weight for the Brazilian economy.

This score corresponds to the combination of the evaluations of the six points of view considered fundamental for the operation of cargo transportation by cabotage, according to the understanding of the decision makers who participated in the construction of the evaluation model; and reflects the situation of shortage, neglect and abandonment faced by shipping companies not only to offer quality cargo transportation services, but also to keep expanding at an annual growth rate higher than the growth rate of Brazilian GDP.

This fact reflects both the willingness of EBNs to continue investing in the expansion of the modal, as well as the cargo transporters' clamor for more efficient, safer and less costly solutions to distribute their products in the national market.

Table 14 presents the scores (on a scale of 0 to 10) for the final assessments of the various criteria and the overall evaluation, the latter resulting from the weighting of the criteria scores, based on the weight defined by the decision makers for each FPV, as shown above.

Table 14. Overall evaluation.

\begin{tabular}{|c|c|c|}
\hline FPV & Weights & FPV Evaluation \\
\hline 1. Port infrastructure & $25 \%$ & 4.9 \\
\hline 2. Port procedures & $20 \%$ & 5.4 \\
\hline 3. Port costs & $16 \%$ & 1.9 \\
\hline 4. Regulatory framework & $13 \%$ & 1.4 \\
\hline 5. Other impacting factors & $14 \%$ & 3.5 \\
\hline 6. Public policies & $12 \%$ & 5.1 \\
\hline Overall evaluation & $100 \%$ & 3.9 \\
\hline
\end{tabular}

Source: Authors, using Hiview3 software.

As can be seen in Table 14, only two criteria scored slightly higher than the acceptable minimum, which would be 5.0. All others were critically evaluated, with scores ranging from 1.4 to 4.9.

The score 4.9 attributed to Port Infrastructure reflects the low levels of investment in this sector, especially with regard 
to the land access roads to the ports and the access channels to the ports, which, in many cases, have limited accessibility due to lack of dredging; it also reflects the management deficiency found in most Brazilian ports, which shirk their role as an active and proactive member of the logistical supply chains, an essential and strategic activity for economic development.

Port procedures, represented by three activities of extreme importance for cabotage - port support, dedicated berthing windows and operational productivity - were assessed with a score of 5.4. This reflects, in a way, the deficiency in port management, the need for better preparation and professionalism of the various private agents who operate in ports, both in terminals and in support activities.

Port costs directly impact cabotage performance, from the negative contribution to the increase in freight costs, which is why this criterion was so poorly evaluated, only 1.9. Such an evaluation shows that both port tariffs and the cost of labor in ports (foreman and stevedoring) and piloting require proficient and energetic actions in order to reverse the current situation.

With regard to piloting, it is understood that some actions can be studied for a possible reduction in the cost of this service, such as: i) releasing the rotation of pilots where there is more than one watchman, so that companies can freely choose the pilot to be hired; ii) flexibility in the rules for qualifying ship captains as pilots; and III) evaluation of the possibility of exemption from the use of the pilot in special situations, depending on the type of vessel and the conditions of the access channels to the ports.

The regulatory framework received, as expected, the worst evaluation among the six criteria that make up the model, only 1.4. This reflects the displeasure of the EBNs in relation to the high tax burden to which they are subject, to the rules for exemption from the practice that are almost impossible to be fulfilled and to the excess of documents that they are required to present in the ports for the release of ships and cargo, thus reducing the productivity of the ships and generating downtime that could be avoided.

The criterion related to other impacting factors was also very poorly evaluated, with a score of 3.5. This fact was due, in large part, to the price of the bunker, since the fuel of cabotage ships does not receive any type of government incentive and is still surcharged with ICMS of 12 to $17 \%$ (such variation depends on the State of Federation), while the ICMS tax rate for the fuel of ships operating in long-distance navigation is zero.

This fact is further aggravated by two points: i) fuel is the main operating cost of ships; and ii) the direct competitor of cabotage, the road modal, operates with subsidized fuel. The other two items in this criterion were rated medium.

Regarding the Public Policies criterion, which was evaluated with a score of 5.1, despite having received one of the highest evaluations among the criteria, it is still a cause for concern. One would expect that the public policies that directly affect cabotage, such as manpower training and financing for the sector, would be fully aligned with the promotion of this modal, but the reality is quite another. An exception is made for the chartering policy, which underwent a new regulation in 2015, whose dictates satisfy the demands of the cabotage sector, having pulled the criterion score upwards.

Analyzing from a macro perspective, one can see that cabotage can be seen as an element capable of contributing to the reduction of the country's logistical cost and, consequently, to the reduction of the so badly propagated "Brazil cost". For this to happen, it is necessary that the volume of cargo transported by cabotage grows exponentially, in order to drastically reduce the price of freight and, consequently, the logistics compound.

It is noticed that there are two conditions for the exponential growth of the cargo transported by cabotage in Brazil: i) the improvement of the operating conditions of this modal; and ii) the entry of new players in this market.

The improvement in the operating conditions of cargo transportation by cabotage depends, necessarily, on three basic points: i) improvement of the infrastructure, either of the ports, or of the accesses to them; ii) exemption from the sector, based on the reduction of the tax burden, port tariffs, labor costs, including pilotage, and tax incentives; and iii) deregulation of the 
sector, with a view to reducing the level of bureaucracy that affects both ships and cargoes.

The entry of new shipping companies in the cabotage cargo transportation segment mainly depends on government incentives and the breaking down of possible barriers to new entrants that, by chance, may exist.

The increase of new companies in the cabotage cargo transportation segment is desirable to increase the competitiveness of the sector and to force the reduction of the freight price, as well as to increase the installed capacity of this modal. According to a demand study commissioned by the company Log-In to the Ilos Institute in 2013, there is a potential demand for containerized cargo that can be transported by cabotage around six times the volume transported in 2015 by this modal (Log-In, 2015).

If the volume of this potential demand, which today is transported by road, were to be carried by cabotage, it would certainly cause a bottleneck in the sector. The coastal shipping companies, currently operating in Brazil, are aware of this reality and are investing in the expansion of their fleets.

However, the expansion of shipping companies operating in this segment would certainly be beneficial to the system and to society in general, as it would promote its oxygenation, with a possible reduction in freight prices, logistical costs, product prices, and economic leverage.

The evaluation model developed and applied brought to the scientific field the problem of evaluating the operating conditions of cargo transportation by the coastal route; it provided solid bases for government and private interventions, aimed at making better use of this mode of transport. This model was corroborated by the results of the sensitivity analysis to which it was submitted and which will be commented on in the following item.

\subsection{Application of sensitivity analysis}

After the field research data had been processed and the criteria evaluations and the global evaluation had been computed, a sensitivity analysis of the multicriteria evaluation model was performed, as recommended in item 4 , the results of which are presented below.

In Figure 6, a graph is presented with the position of potential shares (companies) in the cut-off line of the original substitution rate (25\%) of FPV 1 - Port infrastructure. From this graph, the sensitivity of the model will be tested in this specific criterion, imputing a 10\% variation in the substitution rate, upwards and downwards, in order to verify whether this modification would cause any significant change in the position of the companies, in cut-off line. 
Figure 6. Position of companies on the 25\% FPV cut-off line 1.

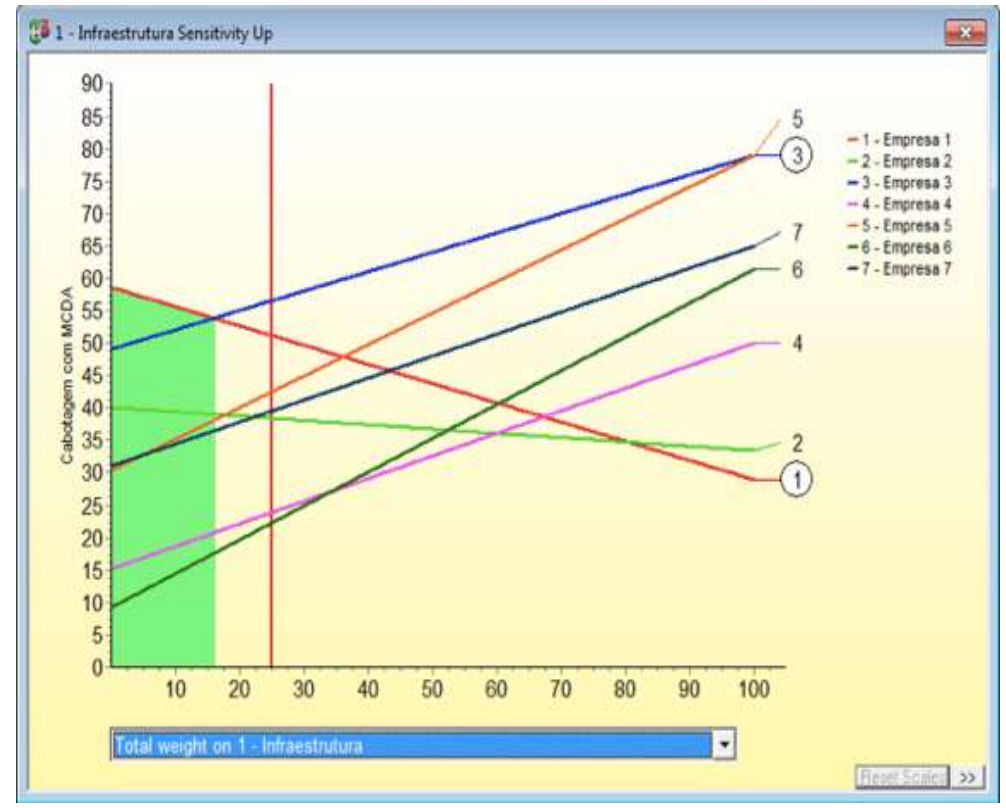

Source: Authors, using Hiview3 software.

The graph in Figure 7 shows that a 10\% variation in the FPV1 replacement rate does not change the position of potential shares on the cut-off line corresponding to $27.5 \%$.

On the other hand, the graph in Figure 8 also shows that there has been no change in the position of the companies in the cut-off line relative to the $10 \%$ downward variation in the replacement rate $(22.5 \%)$.

The test carried out with the FPV 1, indicated that the model, in relation to this specific criterion, is robust, since there was no significant change in the position of the companies, more specifically, the message that the graph brings up is that a small change in the model parameters will not significantly influence the final result of the evaluations.

This same test was applied to all criteria and in no case was there a change in the position of the companies in the cutoff lines after the variations of $10 \%$ up or down, which confirms that the model as a whole is robust and that the results of the criteria and overall evaluations are relevant. 
Research, Society and Development, v. 10, n. 8, e55410817693, 2021

(CC BY 4.0) | ISSN 2525-3409 | DOI: http://dx.doi.org/10.33448/rsd-v10i8.17693

Figure 7. Position of companies in the cut-off line of $27.5 \%$ of FPV1.

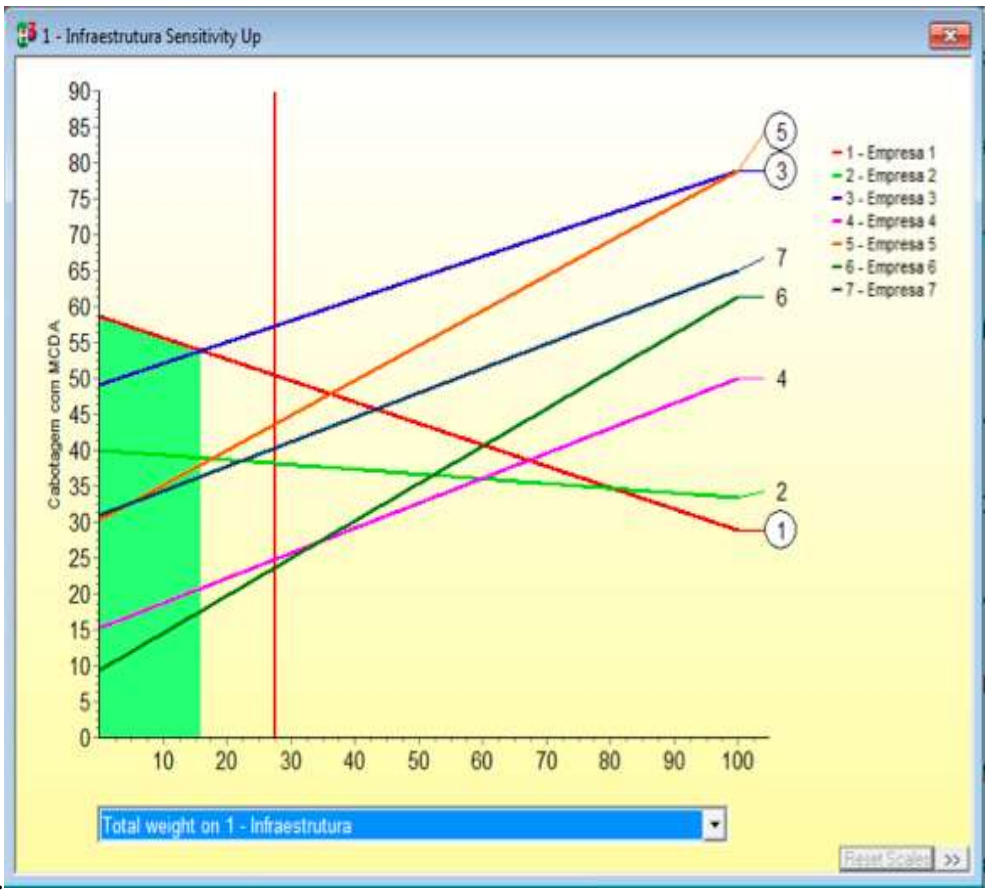

Source: Authors, using Hiview3 software.

Figure 8. Position of companies in the cut-off line of $22.5 \%$ of FPV1.

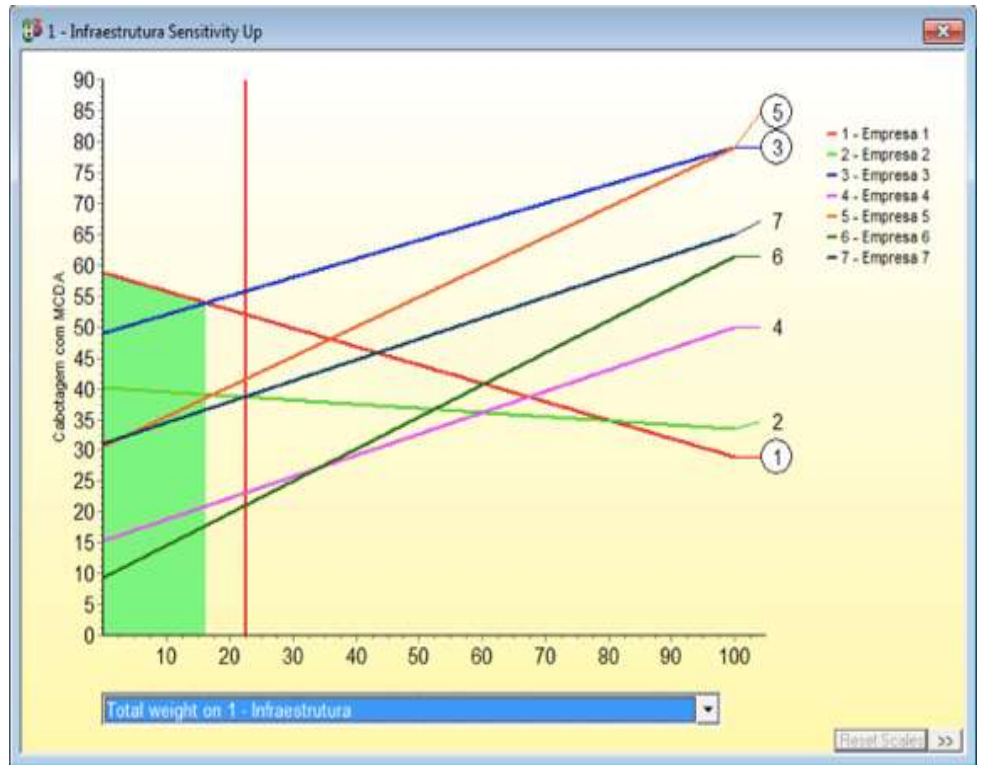

Source: Authors, using Hiview3 software.

\section{Final Considerations}

The purpose of this study was to evaluate the operating conditions of cargo transportation by cabotage in Brazil, from the perspective of shipping companies operating in this segment, with the purpose of quantifying the main factors that directly impact this mode of transport, in terms of effectiveness.

In fact, when reference is made to the main factors that directly impact this mode of transport, it refers to the factors 
that make the system work, which were identified during the construction of the evaluation model, such as port infrastructure, port procedures, port costs, regulatory framework, public policies, and others that, undoubtedly, impact the operationalization of the Brazilian waterway modal, more specifically, cabotage.

In order to carry out such an evaluation, a model based on the multicriteria decision support methodology was built, which is the major contribution of this work to the state of the art of Brazilian cabotage navigation, since, based on the epistemological assumptions and foundations of Multicriteria Decision Aid, and with the support of a team of cabotage navigation specialists, a model was built, under the guidance of the constructivist paradigm, capable of evaluating, quantitatively, the operating conditions of cargo transportation by cabotage in Brazil, from the qualitative perceptions of its operators.

The overall evaluation of the conditions of operation of cabotage transport in Brazil was very low, reaching only a score of 3.9. The justification for such a low assessment certainly depends on the state of shortage, neglect and abandonment that Brazilian cabotage has been experiencing in the last decades, although justice has been done in recent years, there have been efforts, on the part of the government, to reverse this situation. However, what can be noticed is that the actions developed are punctual and disconnected, not being part of a long-term and sustainable strategic planning.

Despite all this, the segment of cargo transport by cabotage has been growing at rates higher than the growth of Brazilian GDP. Even the transport of containerized cargo by cabotage, in the last five years, has been growing at double digit annual average rates, driven by the industrial and agricultural segments that seek alternatives to the high costs and insecurity of road transport.

On the other hand, the cabotage cargo transportation segment, composed of a small number of companies, has been responding to market demands, with investments in new equipment and in better management and operating practices, despite the adverse conditions with which come across.

However, it remains to be seen what the limits of the Brazilian cabotage shipping companies will be if there is a growing demand for this modal at levels higher than those verified today, as is to be expected. Two situations may occur: i) they will continue to invest in increasing their fleets in order to meet the possible growth in demand; or ii) there will be stagnation in the cabotage market, with repercussions on the price of freight (not an ideal situation).

So that the second hypothetical situation does not occur, government incentives are needed to increase Brazilian cabotage, not only to improve the operating conditions of this mode, but also to create conditions for the expansion of the number of shipping companies in this segment.

This proposition is justified mainly by the fact that cargo transportation by cabotage can and should be used by government authorities as an instrument for reducing the country's logistics cost, which, at its current level, causes inconvenience to the economic activity and compromises Brazil's aspirations of becoming a world economic power.

Finally, as a recommendation for future studies, it is suggested that evaluations of this type be carried out every three years to monitor the evolution of the operating conditions of this modal in the face of incentives and increments that may happen.

\section{References}

Alvarenga, H. (2020). Matriz de transportes do Brasil à espera dos investimentos. ILOS. <https://www.ilos.com.br/web/matriz-de-transportes-do-brasil-aespera-dos-investimen tos/>

Barbosa, R. E. (2011). Análise Ambiental das Mudanças da Matriz Logística Brasileira, Previstas no Plano Nacional de Logística e Transportes - PNLT. Universidade Estadual de Goiás. UEG.

BNDES (1998). Cadernos de Infraestrutura - Transporte na Região Amazônica. Banco Nacional de Desenvolvimento Econômico e Social. BNDES.

Borges, I. B., Gonçalves W., \& Freitas, R. R. (2018). Analysis of the expansion of cabotage routes from economic and business sustainability view. Research, Society and Development, 7, e979434. 10.17648/rsd-v7i9.434. 
Research, Society and Development, v. 10, n. 8, e55410817693, 2021

(CC BY 4.0) | ISSN 2525-3409 | DOI: http://dx.doi.org/10.33448/rsd-v10i8.17693

Bouyssou, D. (1986) Some Remarks on the Notion of Compensation in MCDM. European Journal of Operational Researh, 26, $150-160$.

Brasil. (1997). Lei n 9.432, de 08/01/1997: Dispõe sobre a Ordenação do Transporte Aquaviário. Senado Federal, Brasília.

Brasil. (2015a). Agência Nacional de Transportes Aquaviários. Termo de Execução Descentralizada: realização de estudo sobre navegação marítima, englobando os segmentos: longo curso, cabotagem, apoio marítimo e apoio portuário. Antaq/UnB, Brasília.

Brasil. (2015b). Agência Nacional de Transportes Aquaviários. Relatório do Movimento das Embarcações Autorizadas na Navegação de Cabotagem no Período de Janeiro a Outubro de 2015. Antaq, Brasília.

Brasil. (2015c). Secretaria de Portos da Presidência da República/IDOM Consulting. Estudo para Desenvolvimento do Setor de Cabotagem no Brasil. SEP, Brasília.

Brasil. (2015d). Agência Nacional de Transportes Aquaviários. Resolução n. 1, de 13/02/2015: estabelece os procedimentos e critérios para o afretamento de embarcações por empresa brasileira de navegação nas navegações de apoio portuário, apoio marítimo, cabotagem e longo curso. Antaq, Brasília.

Brasil. (2020). Agência Nacional de Transportes Aquaviários. Anuário Estatístico 2019. Agência Nacional de Transporte Aquaviário. <http://www.antaq.gov.br> Camargos, M. A. (2002). Reflexões sobre o Cenário Econômico Brasileiro na Década de 90. Anais do XXI Encontro Nacional de Engenharia de Produção.

Carvalho, R. O., Robles, L. T. \& Assunpção, M. R. (2010). Prestação de Serviços de Logística Integrada à Cabotagem por Armadores que Operam no Porto de Santos: de Porto a Porto a Porta a Porta. Anais do XXX Encontro Nacional de Engenharia de Produção, XXX ENEGEP, São Carlos.

CCE (2004). Comunicação da Comissão relativa ao transporte marítimo de curta distância. Bruxelas. CCE, Bruxelas, Bélgica. <http://eurlex.europa.eu/LexUriServ/LexUriServ.do?uri=COM:2004:

CNT. Confederação Nacional dos Transportes. (2006). Portos Marítimos: Longo Curso e Cabotagem. CNT

CNT. Confederação Nacional dos Transportes. (2013). Pesquisa do Transporte Aquaviário - Cabotagem. Confederação Nacional do Transporte. Brasília. <http://www.cnt.org.br/Paginas/ Pesquisas_Detalhes.aspx?p=9>

Durães Filho, A. C., Gonçalves, L. M., Alves, M. T. A., Nascimento, S. M. R. \& Maciel, G.S. (2011). Cabotagem: uma Alternativa Econômica de Transporte Eficaz para o Brasil. Perspectiva online.

Ensslin, L., Montibeller Neto, G., \& Noronha, S. M. (2001). Apoio à Decisão: Metodologias para Estruturação de Problemas e Avaliação Multicritério de Alternativas. Insular, Florianópolis.

European Comission (2016). Short Sea Shipping. http://ec.europa.eu/transport/modes/maritime/short_sea_shipping/index_en.htm.

Ferreira, A. O. M., Silvino, Z. R., Balbino, C. M., Izu, M., Souza, C. J. \& Matias, D. O. (2020). Multicriteria model for the quality control of geriatric diapers for hospital use. Research, Society and Development, 9, . e753974835, 2020. 10.33448/rsd-v9i7.4835.

Fonseca, F. O. (2012). A Circulação através da Navegação de Cabotagem no Brasil: um Sistema de Fluxos e Fixos Aquaviários Voltados para a Fluidez Territorial. Dissertação de Mestrado em Geografia Humana. Departamento de Geografia da Faculdade de Filosofia, Letras e Ciências Humanas da Universidade de São Paulo, São Paulo.

Keeney, R. L. (1992). Value Focused-Thinking: a Path to Creative Decision-Making. Harvard University Press.

Keeney, R. L. \& Raiffa, H. (1976). Decisions with Multiple Objectives: Preferences and Value Tradeoffs. John Wiley.

Keeney, R. L. \& Raiffa, H (1993). Decision with Multiple Objectives, Preferences and Value Tradeoffs. Cambridge University Press.

Lekakou, M. B. \& Pallis, A. A. (2005). Cruising the Mediterranean Sea: Market structures and EU Policy Initiatives. Aegean Working Papers, 2 , 45-61.

Log-In (2015). A Log-In e a Cabotagem no Brasil. In: Seminário Brasil-Dinamarca, realizado na Antaq, <http://www.antaq.gov.br/Portal/pdf/Palestras/2015/2015_Seminario_Brasil_Dinamarca/Painel3/02_Marcio_Arany.pdf>

Pereira, L. C. H., Damasceno, M. G. F \& Figueiredo, F. N. A. (2010). A Importância da Cabotagem para Integração Logística do Brasil. FIC.

Psaraftis, H. N. (2009). Challenges in European Short Sea Shipping. Anais do $13^{\circ}$ Congress of International Marine Association of the Mediterranean, Istanbul Turkey<http://www.martrans.org/documents/2009/air/IMAM09_template\%20PSARAFTIS\%20KEYNOTE\%203b.pdf>

Quirino, M. G. (2002). Incorporação das Relações de Subordinação na Matriz de Ordenação - Roberts em MCDA quando os Axiomas de Assimetria e de Transitividade Negativa são Violados. Tese de Doutorado em Engenharia de Produção. Universidade Federal de Santa Catarina. Florianópolis.

Reichert, L. J. (2012). Avaliação de Sistemas de Produção de Batata Orgânica em Propriedades Familiares: uma Aplicação da Metodologia Multicritério de Apoio à Decisão (MCDA). Tese de Doutorado em Sistemas de Produção Familiar. Faculdade de Agronomia Eliseu Maciel da Universidade Federal de Pelotas, Pelotas.

Roy, B. (1993). Decision Science or Decision-Aid Science? European Journal of Operational Research. 66, $184-203$.

Roy, B. (1996). Multicriteria Methodology for Decision Aiding. Kluwer Academic Publishers.

Saaty, T. L. (1977). A Scaling Method for Priorities in Hierarchical Structures. Journal of Mathematical Psychology. 15, 234-281. 
Research, Society and Development, v. 10, n. 8, e55410817693, 2021

(CC BY 4.0) | ISSN 2525-3409 | DOI: http://dx.doi.org/10.33448/rsd-v10i8.17693

Silva, L. A. C., Araújo, M. V. P. \& Brito, M. L. A. (2018). Intermodal logistics in the state of Rio Grande do Norte: an exploratory study. Research, Society and Development, 7, e477100. 10.17648/rsd-v7i7.311.

Silveira Jr., A. (2018). Cabotagem brasileira: uma abordagem multicritério. Appris.

Soares, N. M. P (2014). Short Sea como alternativa ao Transporte Terrestre. Dissertação de Mestrado em Logística. Instituto Politécnico do Porto/Instituto Superior de Contabilidade e Administração do Porto

Talley, W. K. (2009). Port Economics. Routledge.

Teixeira, C. A. N., Rocio, M. A. R., Mendes, A. P. A., d'Oliveira, L. A. S. Navegação de cabotagem brasileira. BNDES Setorial n. 45, . $391-436$.

Valois, N. A. L. (2014). Requisitos para modelo de operação da cabotagem de cargas conteinerizada no Brasil: a Utilização de Terminais Rápidos. Tese de Doutorado em Engenharia Naval e Oceânica. Escola Politécnica da Universidade de São Paulo. 